\title{
Queer er en tilstand
}

Af BonNie C. BARr og

\section{Maja BisSENBAKKer FrederiKSEN}

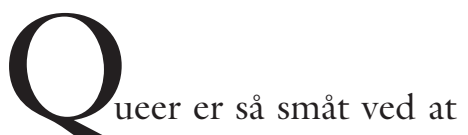

blive en populær teori. Ikke blot er nærværende nummer af Kvinder, Køn \& Forskning helt helliget dette fænomen, men også en række nordiske magasiner og konferencer har i løbet af de sidste par år haft queer på dagsordenen. Både Lambda Nordica og det nu hedengangne Zink har taget emnet op. Også på de enkelte universiteter rundt om i landet har queer teori sneget sig med ind i diverse institutters fagblade, f.eks. i et kommende queer specialnummer af Syddansk Universitets (Odense) tidsskrift for litteratur og sprog Synsvinkler. Konferencen Farväl Heteronormativitet på Göteborgs Universitet satte queer teori i centrum, og den kommende årskonference $\mathrm{i}$ Foreningen for kønsforskning i Danmark, som afholdes på Syddansk Universitet, har ligeledes queer som ramme for begivenhederne. Såfremt den tendens udtrykker, at queer ikke bare er blevet trendy, men måske ligefrem er på vej til at etablere sig som en integreret del af forskningsinstitu- 
tionen, ja så er der et par spørgsmål, der bør stilles: Hvordan skal queer teori formidles og af hvem? Skal man identificere sig som ikke-heteroseksuel for bedst at kunne bedrive queer teori?

Hvad angår det sidste spørgsmål, kan man ved første øjekast foranlediges til at tro, at teorien hovedsageligt beskæftiger sig med seksualiteter og køn, som falder uden for en bestemt version af den heteroseksuelle norm. Dissident seksualitet spiller en forholdsvis stor rolle inden for queer teori, fordi teoriens fortsatte analyser af heteronormativitet oftest tager udgangspunkt i det marginaliserede og ekskluderede. Men samtidig er analyserne også udtryk for et forsøg på at underminere faste identitetskategorier ved at vise dem som kontingente konstruktioner. Det er derfor heller ikke et bestemt kønsligt eller seksuelt udgangspunkt, som betinger god forskning i og formidling af queer teori. Det er en væsentlig queer pointe, at såvel homo- som heteroseksualitet er konstrueret inden for samme (heteronormative) forståelsesparadigme, og man er derfor ikke epistemologisk og videnskabeligt bedre stillet som queerteoretiker, hvis man identificerer sig som ikke-heteroseksuel.

Alligevel kommer man nok ikke uden om, at teorien implicit henvender sig til en læser, som i en eller anden udstrækning er parat til at identificere sig selv som "queer". Dette betyder ikke, at man skal "være" queer for at forstå og arbejde med queer-teori. Det er muligt at positionere sig på andre måder uden samtidig at blive fremmed for teorien. Ejerskab af teorien kan ikke hævdes af nogen. Dette bl.a. fordi selve læsningen af queer tekster åbner muligheden for at "blive gjort" queer. I det omfang læsning kan forstås som en transformativ proces, der performativt konstituerer det læsende subjekt som “queer", kan man sige, at vi alle bliver queer i det øjeblik, vi interpelleres som sådanne af teksten. Queer må altså ikke forstås som noget essentielt. Queer er en tilstand, man kan blive sat i.
På den ene side queeres vi således selv i mødet med teorien. På den anden side er det vigtigt at holde sig for $\varnothing j e$, at mødet med queertekster altid er et situeret møde. Det vil være fejlagtigt at tro, at man kommer til queer teori som en tabula rasa. Som læsere er vi nødvendigvis indlejret i specifikke seksuelle og kønslige kategorier, vi ikke kan undslippe - kun kritisk og pragmatisk forholde os til. Uanset queer teoris nødvendige afstandtagen fra essentialisme, så er det et faktum, at diskurserne om f.eks. homoseksualitet og heteroseksualitet positionerer disse identiteter - og ikke mindst det der falder uden for denne dikotomi forskelligt socialt og kulturelt. Sociale kategorier har ikke essens, men de konstituerer ikke desto mindre effektivt konkret virkningsfulde identiteter, som altid må medreflekteres $\mathrm{i}$ receptionen og formidlingen af queer teori. På trods af den potentielle queer interpellation af læseren medfører queerteksten altså ikke en entydig determinering af det læsende subjekt. Tværtimod må vi forstå læserens position som et element, der uundgåeligt virker tilbage på teksten. Og det er netop i dette rum, mellem tidligere og fremtidige identifikationer og interpellationer, at receptionen af queer teori får sin betydning.

Det er det møde i rummet mellem læser og teori, som bør udforskes nærmere. Tager man udgangspunkt i læserens position gælder det, at man (især når man varetager en teori, der omhandler social identitet) også må forholde sig til den specifikke situerethed, som ens egen identitet betinger. Det er vores refleksioner over, hvordan og med hvilke følger vi selv positioneres af sociale kategorier, der kan iværksætte nye fortolkninger af queer teori.

Hvordan de konkrete konsekvenser af en sådan refleksion i hvert enkelt tilfælde former sig, kan ikke foregribes her, men umiddelbart er der en række spørgsmål, man som udøver af queer-teori, bør stille sig: Hvordan påvirker min specifikke sociale og kulturelle kontekst min reception og for- 
midling af det queer teoretiske begrebsapparat? Hvilke investeringer har jeg selv på spil, når jeg læser og udøver teorien? Hvor befinder jeg mig i forhold til den politiske agenda om social forandring, som queer teori fundamentalt er indskrevet i? Hvilke eksklusioner foretager jeg i min formidling af queer teori?

Før fremtidsvisionen om queer på pensum bliver en realitet (omend denne vision muligvis er utopisk), er det nødvendigt kri- tisk at forholde sig til den queer-teoretiske formidlingsposition. Det er gennem en udforskning af rummet imellem læser og teori, at dørene åbnes for en ny og bredere reception af queer teori, således at denne kan integreres i undervisningen og forskningen.

Bonnie C. Barr, stud.mag. i Nordisk og Køn og Kultur, Syddansk Universitet

Maja Bissenbakker Frederiksen, stud.mag i Nordisk og Filosofi, Syddansk Universitet 